(Aus dem hygienischen Institute der Universität Budapest.

Director: Prof. Leo Liebermann.)

\title{
Beiträge \\ zur Kenntniss der Fermentwirkungen.
}

VIII.

Ueber die Guajakreaction des colloïdalen Platins.

Von

\section{Leo Liebermann.}

Die Guajaktinetur wird durch coll. Platin wie durch Enzyme gebläut. Es frägt sich nun: Haben wir es hier mit einer directen Oxydation der Guajakonsäure dureb den activen Sauerstoff der Platinlösung zu thun, oder nur mit einer Sauerstoffübertragung, von der activen, Sauerstoff fuhrenden Gruppe des Harzes an die Guajakonsäure, oder kann beides stattfinden?

Folgende Versuche beantworten diese Fragen:

1. Wird ganz frisch bereitete Guajaktinctur, welche durch Diastaselösung noch nicht gebläut wird, also noch keinen oder noch nicht genügend Sauerstoff entbält, mit wirksamer, also activen Sauerstoff enthaltender coll. Platinlösung versetzt, so wird sie sofort gebläut, woraus folgt, dass die Platinlösung eine directe oxydative Wirkung ausgeübt hat.

2. Wird die Platinlösung vorher durch längeres Einleiten von Wasserstoff inactivirt, so wird frisch bereitete Guajaktinctur anfangs gar nicht gebläut. Blaufärbung tritt erst später und allmählich in dem Maasse ein, als die Mischung mit der Luft in Berührung tritt, vorzüglich am oberen Rande der Flüssigkeit.

Dies bestätigt also den Schluss, der aus Versuch 1 gezogen wurde.

3. Wird hingegen active, also schon activen Sauerstoff enthaltende Guajaktinctur mit durch Wasserstoff in activirter 
234 Leo Liebermann: Beitr. z. Kenntniss der Fermentwirkungen. VIII.

Platinlösung zusammengebracht, so findet Blaufärbung statt, wenn auch langsamer als mit activer Platinlösung, aber doch durch die ganze Masse der Flüssigkeit, ja sogar weniger am oberen, mit der Luft in Berührung tretenden Rand der Flussigkeit, als unten und in der Mitte. Dies beweist also, dass in diesem Falle eine Übertragung von Sauerstoff durch das coll. Platin stattgefunden hat. Die aufgeworfenen Fragen sind daher, wie folgt, zu beantworten:

Das coll. Platin kann auf die Guajaktinctur in doppelter Weise wirken: sowohl als directes Oxydationsmittel, als auch als Sauerstoffüberträger, von der activen Sauerstoff führenden Gruppe des Harzes zur Guajakonsäuregruppe. 